УДК 343.22:004.8
O. E. Radutniy,

$\mathrm{PhD}$ in Law, Associate Professor of the Department of Criminal Law № 1 of the Yaroslav Mudryi National Law University

\title{
NOVEL CRIMINAL DELICTS RELATED TO DIGITAL HUMAN BEING
}

In continuation of previous research, the article proposes de lege feenda some legal definitions and normative formulations of new forms of socially dangerous behavior that are in one way or another related to digital human being (Homo numeralis, Homo digitalis, Homo Horologium). It is projected that digital human being will no longer be the human being we are used to. It is possible that digital human being will change certain value guidelines.

Key words: artificial intelligence, subject of crime, bioengineering, cyborg, inorganic life form, Homo numeralis, Homo digitalis, Homo horologium, digital human being.

Setting a problem. According to a considerable number of researchers (Andrey Kurpatov, David Eagleman, Dean Burnett, Dee Joy Coulter, Daniel J. Siegel, Dick Frans Swaab, Mariano Sigman, Loretta Graziano Breuning, Mark Hyman, Kaja Nordengen, Paul W. Glimcher, Ryuta Kawashima etc.) the human brain is more powerful than it necessary for the survival of the biological species Homo sapiens. In nature, this occurs only in the case when previously there was destructive competition. Probably that due to this competition Homo habilis, rudolfensis, ergaster, erectus, floresiensis, antecessor, heidelbergensis, neanderthalensis, rhodesiensis, cepranensis, georgicus and other are extinct. Nowaday Homo sapiens is getting with powerful new competitors. They are artificial intelligence and digital human being (Homo digital, Homo numeralis, Homo digitalis, Homo Horologium $)^{1}$. In the sphere of the legal doctrine digital human being can be both a sub-

\footnotetext{
${ }^{1}$ Радутний О. Е. Artificial Intelligence (штучний інтелект) як суб’єкт правовідносин в галузі кримінального права. Політика в сфері боротьби зі злочинністю: матеріали Міжнародної науково-практичної конференції з нагоди відзначення 25-річчя навчально-наукового юридичного інституту. Івано-Франківськ, 2017. С. 200-206; Радутний О. Е. Кримінальна відповідальність штучного інтелекту. Інформація і право / редкол.: В. Г. Пилипчук та ін. К.: Науково-дослідний інститут інформатики і права Національної академії правових наук України, 2017. № 2 (21). С. 124-133; Радутний О. Е. Додаткові аргументи щодо правосуб'єктності шту-
} 
ject of crime and the object of the criminal impact. And both of these aspects require proper legal regulation.

An analysis of recent research and publications on this topic. The issue of considering the circumstances that characterize the person of the criminal has been paid attention in nearly all criminal law works by M. I. Bazhanov, V. S. Batirgareeva, Yu. V. Baulin, V. I. Borisov, I. M. Danshin, L. N. Demidova, O. V.Zaitsev, A. A. Muzika, V. O. Navrotsky, N. I. Panov, V. V. Stashis, V. Ya. Tatziy, V. O. Tulyakov, P. L. Fris, V. I. Shakun, M. I. Khavroniuk, V. B. Kharchenko, V. V. Ustimenko and many others. Significant contributions to the study of the phenomenon of artificial intelligence have been made James Barrat, Eric Horvitz, Niklas Boström, Elon Musk, George Dyson, Kevin Kelly, Ryan Calo, Peter M. Asaro, Vernor Steffen Vinge and many others, in the area of domestic law - by O. A. Baranov, M. V. Karchevskiy, V. A. Misliviy, N. A. Savinova, E. O. Kharitonova, O. I. Kharitonova etc. However, the problem of the legal status of digital human being (Homo digital) is only at the beginning of the study.

The purpose of the study is to formulate de lege ferenda of individual legal definitions and (or) legislative formulations of forms of socially dangerous behavior that are in one way or another related to digital human being.

Presenting main material. Over the last one hundred of the two hundred thousand years of the general history of mankind, human lifespan has increased almost twice, the height has changed considerably, body weight, IQ level and other indicators, but the possibility of extending the boundaries of nature to the species

чного інтелекту. Інтернет речей: проблеми правового регулювання та впровадження: матеріали другої наук.практ. конф., 29 лист. 2018 р., м. Київ. Київ: КПІ ім. Ігоря Сікорського, Вид-во «Політехніка», 2018. С. 46-50; Радутний О. Е. Місце штучного інтелекту в структурі суспільних відносин, які охороняються кримінальним правом. Фундаментальні проблеми кримінальної відповідальності: матеріали наук. полілогу, 7 верес. 2018 р. м. Харків. Харків: Право, 2018. С. 98-102; Радутний О. Суб’єктність штучного інтелекту у кримінальному праві. Право України, 2018. № 1. С.123-136; Радутний О. Е. Розвиток кримінально-правової доктрини у напрямку визнання штучного інтелекту та цифрової людини суб'єктом правовідносин та суб'єктом злочину. Ефективність кримінального законодавства: доктринальні, законотворчі та правозастосовні проблеми ї̈ забезпечення: матер. міжнарод. наук.-практ. кругл. столу (м. Харків, 17 трав. 2019 р.). Харків: Константа, 2019. C. 202-213. 
Homo sapiens today continues not only through evolution. Belief in the possibility and necessity of this is based on transhumanism.

Transhumanism (abbreviated as $\mathrm{H}+\mathrm{or} \mathrm{h}+$ ) is a philosophical movement that advocates for the transformation of the human condition by developing and making widely available sophisticated technologies to greatly enhance human intellect and physiology. Its famous representatives are Nick Bostrom, James Burke, Martin Rees, Allen Buchanan, Dan Brock, Norman Daniels, Daniel Wikler, Hans Moravec, Raymond Kurzweil, Robert Ettinger, others.

Robert Fogel called this path to boundless perfection a technologicalphysiological evolution. A similar concept is called dual inheritance theory. These views are united by the realization that human evolution becomes more artificial than is determined by biology and natural selection. Humanity has learned to interfere with the genetic code, clone organs and produce artificial life. In 2010, a team of researchers led by Craig Venter, for the first time de novo has resynthesized the genome of the bacterium Mycoplasma mycoides and placed it into the cell of another microorganism Mycoplasma capricolum ${ }^{2}$.

According to Michio $\mathrm{Kaku}^{3}$, the possibility of combining carbon technology (human) with silicon technology (artificial intelligence, implants, objects of robotics), or transfer the structure of the human brain, one neuron by one to inorganic or semi-organic carrier, should be classified to the first class of impossibilities, which is impossible only today (more precisely, as of the year of the first edition of «Physics of the Impossible»), but at the same time does not violate the known laws of nature, because of which it can be realized in the closest sometimes.

Improvement of a person occurs in the following main directions:

1) bioengineering (interference in the human organism at the cellular and atomic levels; development of hybrid nanorobots based on synthetic proteins; im-

\footnotetext{
${ }^{2}$ Clyde A. Hutchison, Ray-Yuan Chuang and others. Design and synthesis of a minimal bacterial genome. Science. 2016. 25 Mar. URL: https://science.sciencemag.org/content/351/6280/aad6253/ (дата звернення: 15.05.2020).

${ }^{3}$ Kaku M. Physics of the Impossible: A Scientific Exploration Into the World of Phasers, Force Fields, Teleportation, and Time Travel. Duke University Libraries: Doubleday Publishing, 2008. P. 233.
} 
plantation of reconstructed DNA; obtaining stem cells from liver adipose tissue cells; growing organs to order or 3D printing them; insertion of Neanderthal DNA into the egg of a modern woman Homo Sapiens as a surrogate mother ${ }^{4}$; in 2017 researchers from the Scripps Center for Mass Spectrometry and Metabolomics created a semi-synthetic organism with artificial DNA; Swiss artificial dosage viruses capable of suppress the immune system and forcing it to direct-kill killer cells to fight cancer; a successful attempt to remove from the human embryo a DNA defect responsible for heart disease (potentially such a technology will be able to «purify» the genes of all humans from inherited diseases), etc.);

2) the creation of a living being that combines organics with inorganics, or the formation of a cybernetic organism (cyborg) - a biological organism that contains mechanical and / or electronic components (eg., cochlear implants to renew hearing and take it on a new level); iBrain Neurointerface for fine motor control, tested by Stephen Hawking; replacement of human amputated limbs with technological prostheses, including an i-LIMB Pulse artificial arm or a knee prosthesis capable to self-training with artificial intelligence RheoKnee developed by Ossur company; retinal prosthesis in the form of a microchip by Retina Implant; artificial heart by Total Artificial Heart; EnChroma glasses for color perception, etc.);

3) creation of an inorganic life form (copying or complete transfer consciousness every part of it on the primary carrier, intelligence and personality of the human to digital or other medium; scanning of the human brain and renewal of its electronic copy, variant that is investigated by neurologist Steven Novella from Yale University ${ }^{5}$; the acquisition of digital immortality with the ability to transfer the identity to the «cloud» of the corresponding server, or due to the spraying by blockchain technology, which could become possible as soon as the decryption of

\footnotetext{
${ }^{4}$ Wade Nicholas. Scientists in Germany Draft Neanderthal Genome. New York Times. 2009. February 12. URL: http://www.nytimes.com/2009/02/13/science/13neanderthal.html/ (дата звернення: 15.05.2020).

${ }_{5}^{5}$ Novella Steven. The Continuity Problem. Neuroscience. 2013. Apr. 23, URL: https://theness.com/ neurologicablog/index.php/the-continuity-problem/ (дата звернення: 15.05.2020).
} 
the connectome (a full description of the structure ${ }^{6}$ of human brain connections completes.

In this regard, there is a real risk that new types of criminal offenses may be committed, including:

- the use of improved physical (strength, agility, speed, endurance, flexibility, etc.) and cognitive abilities of the person (perception of all signals of the surrounding world, including ultrasound and infrasound, perfect memory, processing large amounts of information and decision-making process at accelerated speeds (seconds and milliseconds), concentration of attention, etc.) to facilitate of commission of traditional crimes;

- unlawful use of the results of the combination of biology with information technology, manipulation of substances on an atomic or molecular scale using nanotechnology;

- the development and exploitation personalized biological weapons that is using unique biological, including genetic, information from a specific person or specific human group;

- artificial forgery and using, including at the scene of a crime, blood, saliva or other biological material from the DNA profile of a particular person or a specific human group;

- genetic discrimination, the creation of new biological species with the aid synthetic biology ${ }^{7}$;

- the identification of thoughts (the definition of an object that the person thinks) by the help of devices based on functional magnetic resonance imaging ${ }^{8}$,

\footnotetext{
${ }^{6}$ Olaf Sporns, Giulio Tononi, Rolf Kötter. The Human Connectome: A Structural Description of the Human Brain. PLOS Computational Biology. 2005. September 30. URL: https://journals.plos.org/ploscompbiol/ article?id=10.1371/journal.pcbi.0010042/ (дата звернення: 15.05.2020).

${ }^{7}$ Goodman Marc. A vision of crimes in the future. TEDGlobal. 2012. July. URL: https://www.ted.com/ talks/marc_goodman_a_vision_of_crimes_in_the_future/discussion?language=en/ (дата звернення: 15.05.2020).

${ }^{8}$ Stahl Lesley. How Technology May Soon "Read" Your Mind - Incredible Research Lets Scientists Get A Glimpse At Your Thoughts. CBS News. 2008. Dec 31. URL: https://www.cbsnews.com/news/how-technology-maysoon-read-your-mind/ (дата звернення: 15.05.2020).
} 
suggestion of thoughts using similar technologies, control and manipulation, including for the purpose of using during the crime;

- illegal interference in the work of devices such as, the above-mentioned cochlear implants, retinal prosthesis, etc.);

- creation of a duplicate of a person, illegal copying or complete transfer (without remnants of the primary medium) of consciousness, intelligence and individuality of the person (himself or the outsider) to a digital or other medium, the use of these duplicates for committing a criminal offense;

- appropriation and (or) use of another's personality on the basis of forgery and / or copying of genetic features of the biological body and / or information personality by mastering its digital footprint;

- rape or other violence against a virtual character (avatar) that causes damage to its owner due to their almost complete identification (in a case investigated by the Belgian police, a malicious computer program allowed the aggressor to gain full control of the victim's avatar persons in the Second Life game and graphically committing violent sexual abuse ${ }^{9}$;

- unlawful return personality of dead people to the digital information space (uploading all the information about him / her accumulated up to the moment of death, adding to his / her memories of relatives into the algorithm of artificial intelligence), etc.

Moreover, cannot be ruled out the possibility of a new upper class of people or a new caste. Given that, not to all and far from immediately the results of these revolutionary achievements will be available. Only hundreds or thousands of people which will own some technology or the corresponding neural networks may find themselves on top of the world pyramid. However, the question remains of whether a digital person, as an ordinary human, will share modern values, because

\footnotetext{
${ }^{9}$ Duranske Benjamin. Reader Roundtable: «Virtual Rape» Claim Brings Belgian Police to Second Life. Virtually Blind - Virtual Law - Legal Issues That Impact Virtual Worlds. 2007. April 24, URL: http://virtuallyblind.com/2007/04/24/open-roundtable-allegations-of-virtual-rape-bring-belgian-police-to-secondlife/ (дата звернення: 15.05.2020).
} 
changing needs and lifestyles (eg., longevity or immortality) can trigger a change in value orientations.

To respond to selected issues raised in this and previous studies ${ }^{10}$, proposed de lege ferenda legal definitions and (or) legislative formulations of forms of socially dangerous behavior are as follows:

- «a crime is also considered to have been committed in complicity if it involved an able individual who has reached the age of criminal responsibility and a copy of his / her identity and (or) intelligence embodied in a robotics object, copied to a digital or other media, including in the «cloud» of the server or sprayed by blockchain technology»;

- «a legally significant act is considered to have been committed by an able individual who has reached the age of criminal responsibility, if it was committed by a verified copy of his / her identity and / or intelligence embodied in a robotics object, copied to digital or other media, including number in the «cloud» of the corresponding server or sprayed by blockchain technology»;

- «the limits of prosthetics (implantation) of the human body, according to which an ordinary human is transformed from a biological being into an artificial intelligence, electronic personality or object of robotics are determined by the current legislation of Ukraine»;

- «the use of improved physical (strength, agility, speed, endurance, flexibility, etc.) and cognitive characteristics may be taken into account as a qualifying circumstance in the norm of the Special Part of the Criminal Code of Ukraine, or a circumstance that aggravated the punishment under Art. 67 of the Criminal Code of Ukraine»;

\footnotetext{
${ }^{10}$ Радутний О. Е. Кваліфікуючі ознаки, пов’язані з досягненнями наукового прогресу (біоінженерія, штучний інтелект, неорганічна та змішана форма життя). Актуальні проблеми кримінального права, кримінологї та кримінально-виконавчого права: матер. Всеукр. наук.-практ. конф. (25 трав. 2018 р., м. Дніпро). Дніпро: Дніпроп. держ. ун-т внутр. справ, 2018. С. 41-43; Радутний О. Е. Правові аспекти феномену цифрової людини в кібернетичному та іншому просторі. Забезпечення кібербезпеки: правові та технічні аспекти: Збірник тез наукових доповідей науково-практичного семінару, 8 листопада 2018 р., м. Харків. Харків: Нац. аерокосм. ун-т ім. М. Є. Жуковського «ХAI», 2018. С. 57-63.
} 
- «illegal collection or use of personal information (state of health, emotional state, level and ratio of hormones, location according to geolocation data, etc.) is punished...»;

- «unlawful interference with the implant, microchip, neurointerface, RFIDtattoo on human skin, nanorobot, nanoassembler or prosthesis, etc., as well as the deliberate placement of certain vulnerabilities in them, if it has led to a significant violation of legal rights or protected interests of individuals or legal person, is punished ...»;

- «bringing to criminal responsibility knowingly innocent person by an investigator, prosecutor or other authorized person, combining with forgery and (or) use, including at the crime scene, of blood, saliva or other biological materials from DNA profile an individual or a certain group of people, is punished ...»;

- «deliberately false report to the court, prosecutor, investigator or pre-trial investigation about the commission of a crime, combined with forgery and (or) use, including at the crime scene, of blood, saliva or other biological materials from DNA profile an individual or a certain group of people, is punished ...»;

- «forgery of evidence and (or) their use, including at the crime scene, of samples of blood, saliva or other biological materials from the DNA profile of a particular person or a particular human group, is punished ...»;

- «genetic discrimination, illegal creation of new biological species using synthetic biology, is punished ...»;

- «identification of thoughts, among them definition of the object about which the person thinks, by means of devices, including based on functional magnetic resonance tomography, suggestion of thoughts by means of technologies, mind control and manipulation of consciousness, including for the purpose of using during the commission of a crime, influence during the voting in elections or referendums, is punished ...»;

- «illegal creation of a duplicate of identity, illegal copying or complete transfer (without remnants on the primary medium) of consciousness, intelligence 
and individuality of the person (himself or the outsider) to a digital or other media, the use of these duplicates to commit a criminal offence or other illegal acts, is punished...»;

- «appropriation and (or) use of another's identity based on the forgery and (or) copying of genetic features of a biological body and (or) information personality by taking its digital footprint is punished...»;

- «rape or other violence against a virtual person (avatar), which causes harm to its owner, is punished...»;

- «illegal return the digital identity of the deceased to the cyberspace, including by loading into the algorithm of artificial intelligence all the information accumulated until person death, adding memories of loved ones, is punished...» and so on.

Conclusions. Modern research in the field of bioengineering, the creation of living beings that combine organic with inorganic, and the emergence of inorganic life forms can significantly affect legal doctrine, including in the field of criminal law and information security. In the future, it is possible to take into account as an aggravating (Article 67 of the Criminal Code of Ukraine) or qualifying circumstances the presence of implants that improve physical and (or) cognitive abilities, to formulate legal definitions and certain types of crimes. In them, digital human being (Homo numeralis, Homo digitalis, Homo Horologium) can become not only a subject of relations and offenses, but also an object of criminal influence and socially dangerous encroachment. It is predicted that digital human being will no longer be the human being we are accustomed. The possibility of changing in digital human being some values guide are not being ruled out. Similarly, the possibility of a new upper class of people or a new caste is not ruled out, when at the top of the world pyramid will be only those hundreds or thousands who will have certain technologies or relevant neural networks. 


\section{REFERENCES}

1. Clyde A. Hutchison, Ray-Yuan Chuang and others. Design and synthesis of a minimal bacterial genome. Science. 2016. 25 Mar. URL: https://science.sciencemag. org/content/351/6280/aad6253/ (дата звернення: 15.05.2020).

2. Duranske Benjamin. Reader Roundtable: «Virtual Rape» Claim Brings Belgian Police to Second Life. Virtually Blind - Virtual Law - Legal Issues That Impact Virtual Worlds. 2007. April 24, URL: http://virtuallyblind.com/2007/04/24/ open-roundtable-allegations-of-virtual-rape-bring-belgian-police-to-second-life/ (дата звернення: 15.05.2020).

3. Goodman Marc. A vision of crimes in the future. TEDGlobal. 2012. July. URL: https://www.ted.com/talks/marc_goodman_a_vision_of_crimes_in _the_future/discussion?language=en/ (дата звернення: 15.05.2020).

4. Kaku M. Physics of the Impossible: A Scientific Exploration Into the World of Phasers, Force Fields, Teleportation, and Time Travel. Duke University Libraries: Doubleday Publishing, 2008. 456 p.

5. Novella Steven. The Continuity Problem. Neuroscience. 2013. Apr 23, URL: https://theness.com/neurologicablog/index.php/the-continuity-problem/ (дата звернення: 15.05.2020).

6. Novella Steven. The Continuity Problem. Neuroscience. 2013. Apr 23, URL: https://theness.com/neurologicablog/index.php/the-continuity-problem/ (дата звернення: 15.05.2020).

7. Stahl Lesley. How Technology May Soon "Read" Your Mind - Incredible Research Lets Scientists Get A Glimpse At Your Thoughts. CBS News. 2008. Dec 31. URL: https://www.cbsnews.com/news/how-technology-may-soonread-your-mind/ (дата звернення: 15.05.2020).

8. Wade Nicholas. Scientists in Germany Draft Neanderthal Genome. New York Times. 2009. February 12. URL: http://www.nytimes.com/2009/02/13/ science/13neanderthal.html/ (дата звернення: 15.05.2020).

9. Радутний О. Е. Artificial Intelligence (штучний інтелект) як суб'єкт правовідносин в галузі кримінального права. Політика в сфері боротьби зі злочинністю: матеріали Міжнародної науково-практичної конференції з нагоди відзначення 25-річчя навчально-наукового юридичного інституту. Івано-Франківськ, 2017. С. 200-206.

10. Радутний О. Е. Кримінальна відповідальність штучного інтелекту. Інформачія $і$ право / редкол.: В. Г. Пилипчук та ін. К.: Науково-дослідний інститут інформатики і права Національної академії правових наук України, 2017. № 2 (21). С. 124-133.

11. Радутний О. Е. Додаткові аргументи щодо правосуб'єктності штучного інтелекту. Інтернет речей: проблеми правового регулювання та впровадження: матеріали другої наук.-практ. конф., 29 лист. 2018 р., м. Київ. Київ: КПІ ім. Ігоря Сікорського, Вид-во «Політехніка», 2018. С. 46-50. 
12. Радутний О. Е. Місце штучного інтелекту в структурі суспільних відносин, які охороняються кримінальним правом. Фундаментальні проблеми кримінальної відповідальності: матеріали наук. полілогу, 7 верес. 2018 р. м. Харків. Харків: Право, 2018. С. 98-102.

13. Радутний О. Суб'єктність штучного інтелекту у кримінальному праві. Право Украӥни, 2018. № 1. С.123-136.

14. Радутний О. Е. Розвиток кримінально-правової доктрини у напрямку визнання штучного інтелекту та цифрової людини суб'єктом правовідносин та суб'єктом злочину. Ефективність кримінального законодавства: доктринальні, законотворчі та правозастосовні проблеми ії забезпечення: матер. міжнарод. наук.-практ. кругл. столу (м. Харків, 17 трав. 2019 р.). Харків: Константа, 2019. С. 202-213.

15. Радутний О. Е. Кваліфікуючі ознаки, пов'язані з досягненнями наукового прогресу (біоінженерія, штучний інтелект, неорганічна та змішана форма життя). Актуальні проблеми кримінального права, кримінології та кримінально-виконавчого права: матер. Всеукр. наук.-практ. конф. (25 трав. 2018 р., м. Дніпро). Дніпро: Дніпроп. держ. ун-т внутр. справ, 2018. С. 41-43.

16. Радутний О. Е. Правові аспекти феномену цифрової людини в кібернетичному та іншому просторі. Забезпечення кібербезпеки: правові та технічні аспекти: Збірник тез наукових доповідей науково-практичного семінару, 8 листопада 2018 р., м. Харків. Харків: Нац. аерокосм. ун-т ім. М. Є. Жуковського «ХАI», 2018. С. 57-63.

\section{REFERENCES}

1. Clyde, A. Hutchison, Ray-Yuan Chuang and others. (2016). Design and synthesis of a minimal bacterial genome. Science, 5 Mar. URL: https://science. sciencemag.org/content/351/6280/aad6253.

2. Duranske Benjamin. (2007). Reader Roundtable: «Virtual Rape» Claim Brings Belgian Police to Second Life. Virtually Blind - Virtual Law - Legal Issues That Impact Virtual Worlds, April 24th. URL: http://virtuallyblind.com/2007/04/ 24/open-roundtable-allegations-of-virtual-rape-bring-belgian-police-to-second-life.

3. Goodman, Marc. (2012). A vision of crimes in the future. TEDGlobal, July URL: https://www.ted.com/talks/marc_goodman_a_vision_of_crimes_in_ the_future/discussion?language $=\mathrm{en} /$.

4. Kaku, M. (2008). Physics of the Impossible: A Scientific Exploration Into the World of Phasers, Force Fields, Teleportation, and Time Travel. Duke University Libraries: Doubleday Publishing.

5. Novella Steven. (2013). The Continuity Problem. Neuroscience, Apr 23. URL: https://theness.com/neurologicablog/index.php/the-continuityproblem/. 
6. Olaf Sporns, Giulio Tononi, Rolf Kötter. (2005). The Human Connectome: A Structural Description of the Human Brain. PLOS Computational Biology, September 30. URL: https://journals.plos.org/ploscompbiol/article?id=10. 1371/journal.pcbi.0010042/.

7. Stahl, Lesley. (2008). How Technology May Soon «Read» Your Mind - Incredible Research Lets Scientists Get A Glimpse At Your Thoughts. CBS News, Dec 31. URL: https://www.cbsnews.com/news/how-technology-may-soonread-your-mind/.

8. Wade, Nicholas. (2009). Scientists in Germany Draft Neanderthal Genome. New York Times, February 12. URL: http://www.nytimes.com/2009/02/13/ science/13neanderthal.html.

9. Radutnyy, O.E. (2017). Artificial Intelligence (shtuchnyy intelekt) yak sub"yekt pravovidnosyn v haluzi kryminal'noho prava. Polityka $v$ sferi borot'by zi zlochynnistyu: materialy Mizhnarodnoyi naukovo-praktychnoyi konferentsiyi $z$ nahody vidznachennya 25-richchya navchal'no-naukovoho yurydychnoho instytutu. Ivano-Frankivs'k, 200-206 [in Ukrainian].

10. Radutnyy, O.E. (2017). Kryminal'na vidpovidal'nist' shtuchnoho intelektu. Informatsiya $i$ pravo. V.H. Pylypchuk (Ed.). K.: Naukovo-doslidnyy instytut informatyky i prava Natsional'noyi akademiyi pravovykh nauk Ukrayiny, 2 (21), 124-133 [in Ukrainian].

11. Radutnyy, O.E. (2018). Dodatkovi arhumenty shchodo pravosub"yektnosti shtuchnoho intelektu. Internet rechey: problemy pravovoho rehulyuvannya ta vprovadzhennya: materialy druhoyi nauk.-prakt. konf., 29 lyst. 2018 r., m. Kyyiv. Kyyiv: KPI im. Ihorya Sikors'koho, Vyd-vo «Politekhnika», 4650 [in Ukrainian].

12. Radutnyy, O.E. (2018). Mistse shtuchnoho intelektu $v$ strukturi suspil'nykh vidnosyn, yaki okhoronyayut'sya kryminal'nym pravom. Fundamental'ni problemy kryminal'noyi vidpovidal'nosti: materialy nauk. polilohu, 7 veres. 2018 r. m. Kharkiv. Kharkiv: Pravo, 98-102 [in Ukrainian].

13. Radutnyy, O. (2018). Sub"yektnist' shtuchnoho intelektu u kryminal'nomu pravi. Pravo Ukrayiny - Law of Ukraine, 1. 123-136 [in Ukrainian].

14. Radutnyy, O.E. (2019). Rozvytok kryminal'no-pravovoyi doktryny u napryamku vyznannya shtuchnoho intelektu ta tsyfrovoyi lyudyny sub"yektom pravovidnosyn ta sub"yektom zlochynu. Efektyvnist' kryminal'noho zakonodavstva: doktrynal'ni, zakonotvorchi ta pravozastosovni problemy yiyi zabezpechennya: mater. mizhnarod. nauk.-prakt. kruhl. stolu (m. Kharkiv, 17 trav. 2019 r.). Kharkiv: Konstanta, 202-213 [in Ukrainian]. 
15. Radutnyy, O.E. (2018). Kvalifikuyuchi oznaky, pov"yazani z dosyahnennyamy naukovoho prohresu (bioinzheneriya, shtuchnyy intelekt, neorhanichna ta zmishana forma zhyttya). Aktual'ni problemy kryminal'noho prava, kryminolohiyi ta kryminal'no-vykonavchoho prava: mater. Vseukr. nauk.prakt. konf. (25 trav. 2018 r., m. Dnipro). Dnipro: Dniprop. derzh. un-t vnutr. sprav, 41-43 [in Ukrainian].

16. Radutnyy, O.E. (2018). Pravovi aspekty fenomenu tsyfrovoyi lyudyny $\mathrm{v}$ kibernetychnomu ta inshomu prostori. Zabezpechennya kiberbezpeky: pravovi ta tekhnichni aspekty: Zbirnyk tez naukovykh dopovidey naukovo-praktychnoho seminaru, 8 lystopada 2018 r., m. Kharkiv. Kharkiv: Nats. aerokosm. un-t im. M. Ye. Zhukovs'koho «KHAI», 57-63 [in Ukrainian].

\section{Радутний О. Е. Нові кримінально-правові делікти, які пов'язані 3 цифровою людиною}

У продовження попередніх досліджень в статті пропонуються de lege ferenda окремі правові дефініції та нормативні формулювання нових форм суспільно небезпечної поведінки, які тим чи іншим чином пов'язані з иифровою людиною (digital human being, Ното numeralis, Homo digitalis, Hото Horologium). Прогнозується, щүо цииррова людина вже не буде людською істотою, до якої ми звикли. Не виключається можливість того, щэо у цииррової людини зазнають змін певні иіннісні орієнтири.

Ключові слова: штучний інтелект, суб'єкт злочину, біоінженерія, кіборг, неорганічна форма життя, изифрова людина, Hото пuтеralis, Hoто digitalis, Homo horologium, digital human being.

\section{Радутный А. Э. Новые уголовно-правовые деликты, связанные с цифровым человеком}

В продолжение предыдущих исследований в статье предлагаются dе lege ferenda отдельные правовые дефиниции и нормативные формулировки новых форм общественно опасного поведения, которые тем или иным образом связаны с иифровым человеком (digital human being, Hото numeralis, Hoто digitalis, Hoто Horologium). Прогнозируется, что цифровой человек уже не будет человеческим существом в привычном смысле. Не исключается возможность того, что у иифрового человека претерпят изменения определенные ценностные ориентиры.

Ключевые слова: искусственный интеллект, субъект преступления, биоинженерия, киборг, неорганическая форма жизни, цифровой человек, Homo numeralis, Homo digitalis, Homo horologium, digital human being. 